\title{
Varieties of Capitalism and Fiscal Stimulus, 2008-2010
}

\author{
Nicholas Toloudis \\ The College of New Jersey \\ 2000 Pennington Road, \\ Ewing, NJ 08628, U.S.A. \\ E-mail: toloudin@tcnj.edu
}

\begin{abstract}
This paper tests the Varieties of Capitalism (VoC) framework to explain variation in fiscal stimulus measures across OECD countries in response to the 2008-2010 economic crisis. Following Soskice (2007), I argue that coordinated market economies are less flexible with fiscal policy than liberal market economies. Multivariate analysis across 23 OECD countries demonstrates that VoC is more powerful than three competing theories: fiscal institutions, which hypothesizes more stimulus in countries with less restrictive budgetary rules; debt credibility, which hypothesizes more stimulus in less indebted countries; and political partisanship, which hypothesizes more stimulus in countries governed by the left.
\end{abstract}

Keywords: fiscal policy, fiscal stimulus, government debt, institutions, OECD, varieties of capitalism

\section{Introduction}

Over the past twenty-five years, governments across the advanced industrialized democracies have understood fiscal discipline to be the main macroeconomic problem to be solved. Pontusson and Raess $(2015$, p. 1) note that "political economists seem to have become convinced that governments are no longer willing or able to respond to economic downturns by engaging in fiscal stimulus". This paper examines a brief, but important, deviation from this trend: the discretionary fiscal stimulus efforts enacted from late 2008 to early 2010. In November of 2008, as the magnitude of the banking system's meltdown were felt across the world, the G20 encouraged its members to engage in discretionary spending and tax cutting to limit the social consequences of the economic downturn. The EU proposed a 200 billion euro fiscal stimulus package later that 
month and, since the EU lacks substantial fiscal capacity, directed the Member States to contribute 85 per cent of the total cost and design the precise contents (Cameron, 2012). The US followed in January of 2009, with a fiscal stimulus package of nearly 800 billion dollars in tax cuts and spending increases, and Canada and other countries followed close behind. By the end of 2010, the sovereign debt crisis had created a wide-ranging concern with fiscal austerity, which has remained the order of the day since then.

The discretionary stimulus measures among OECD countries during this period yield an opportunity to examine the determinants of discretionary fiscal expansion under circumstances quite different from the renewed commitment to fiscal austerity that has been so influential since 2010. The purpose of this paper is to test the varieties of capitalism framework ( $\mathrm{VoC}$ hereafter) for its predictive power in understanding discretionary fiscal policy in the advanced industrialized democracies in this unusual circumstance. Some scholars have theorized about the relationship between different models of capitalism and fiscal policy (Soskice, 2007; Iversen \& Soskice, 2006), and others have tested their models with time series cross-sectional data from 1980 to 2009- the period of neoliberal ascendance (Amable \& Azizi, 2014). But can VoC explain the extent of discretionary fiscal stimulus in the wake of a crisis that shook the foundations of this ascendance? I show that it can. Regression analysis confirms that regimes characterized by political economic coordination enacted smaller stimuli than less coordinated regimes. This suggests that, in spite of some statements to the contrary (e.g., Bermeo \& Pontusson, 2012; Pontusson \& Raess, 2012a), VoC does have some explanatory power in understanding the magnitude of fiscal policy response to crisis.

\section{Varieties of Capitalism and fiscal policy}

The dominant $\mathrm{VoC}$ approach to comparative political economy seeks to explain the behavior not of governments, but of firms to model variations between (and to a lesser extent, among) different kinds of capitalism (Hall \& Soskice, 2001; Hancké, 2007; 2009). VoC proposes that a series of interlocking institutionsincluding banking systems, collective bargaining agreements, plant-level mechanisms for worker participation, welfare states, and vocational education and training systems - shape the contours of firm behavior. These institutions establish cycles of mutual reinforcement over time whereby institutional change becomes increasingly difficult. This approach yields a bipartite classification, 
with liberal market economies (LMEs) and coordinated market economies (CMEs) representing different models of institutional configuration that can produce economic growth in an increasingly competitive international environment.

From within this paradigm, David Soskice (2007) suggests that LMEs will be more flexible and discretionary than CMEs when it comes to fiscal policy, because the more consensual forms of decision-making in the latter generate pressures for conservative discretionary fiscal policy that do not exist in the former. This pressure is grounded in an implicit acceptance of the limits of fiscal expansion. Tacit collective responsibility for fiscal prudence becomes predicated on the idea that interest groups that remain unsatisfied with their share of public goods will still be well-served by the longer-term benefits of a government's fiscal tightness and the promise of material gains in the future. This logic does not play out in LMEs, Soskice (2007) suggests, because the general, short-term skill sets that characterize LME workforces, in combination with their means-tested, market-oriented welfare states, generate high levels of demand for social protections and industrial assistance in times of economic crisis. In these regimes - with fewer social protections, lower macroeconomic costs to unemployment, and many collective actors mobilized for politicspoliticians will have more incentives to cater to short-term electoral pressures and engage in less disciplined fiscal policy. No institutions exist in LMEs to constrain governments' willingness to pacify the demands of a wide range of actors in times of crisis.

The only study testing the Soskice (2007) model with a large panel dataset is Amable and Azizi (2014). These authors conduct four sets of regression analyses, one for a complete set of 18 countries, one only for LMEs, one only for CMEs, and one for the so-called mixed economies (namely Portugal, Spain, and Italy). However, contrary to the model, they find that LMEs respond more moderately to economic shocks than CMEs. The authors explain this result in terms of CMEs' core constituency of skilled workers who would be more likely to push for expansionary fiscal policy during recessions, since job layoffs would be more likely during such periods when fiscal expansion would complement welfare state generosity. In LMEs, the lack of such a constituency, combined with the presence of stronger capitalist-rentier coalitions, suggests more political pressure for cyclical fiscal policy.

Why, contrary to Amable and Azizi (2014), might VoC be a more powerful predictor of discretionary fiscal policy shift during the crisis period of 20082010 than during a period of relative normalcy? After all, Hall and Soskice 
(2001) and Soskice (2007) assume relatively stable economic conditions in their models, including a normal business cycle and flexible finance. Their models were not built to understand short-term policy response. One possibility is that institutional complementarities induce restraint more effectively when the exigencies of economic crisis are at their most acute. This is because the concern with public debt never entirely vanishes; governments recognize the political and social value of additional public spending and tax cuts even as they remain attentive to the dangers of excessive debt. The highly skilled workers that Amable and Azizi (2014, p. 6) point to for explaining their results might play a different role in periods of financial crisis: since their livelihoods rely on growth in high-end manufacturing jobs that required substantial private sector investment, their representatives may be more likely to push for more constrained fiscal expansion when (or if they believe) a financial crisis intensifies investors' worry about the impact of debt on the bond markets. Essentially, then, the common experience of economic crisis may induce fiscal expansion across the OECD, but high levels of institutional coordination foster reluctance to running up more debt. This may be connected to the shift from "social Keynesianism" to "liberal Keynesianism" (Bermeo \& Pontusson, 2012; Pontusson \& Raess, 2012a; 2012b; Raess \& Pontusson, 2015), or it may have to do with the nature of the 2008-2009 crisis as a banking crisis that, in Europe at least, became a sovereign debt crisis in 2010.

In the current paper, I deviate from Amable and Azizi's (2014) analysis in two ways. First, they treat varieties of capitalism as a constant by which to sort cases into their three categories-liberal, coordinated, and mixed. However, plenty of research since Hall and Soskice's (2001) original statement explores how and the degree to which countries' institutional complementarities change over time and within the LME/CME clusters (Hall \& Gingerich, 2009; Thelen, 2004; Hall \& Thelen, 2009; Hancké, 2007). Large-N analysis (Schneider \& Paunescu, 2011) and case studies of, for example, Denmark (Campbell \& Pedersen, 2007) and France (Schmidt, 2003; Carney, 2006) have documented and explained these changes. Relatedly, some scholarship has sought to construct indices of coordination to show quantitative evidence (through factor analysis) that countries cluster around two poles of coordination/liberalism (e.g., Hall \& Gingerich, 2004; 2009; Knell \& Srholec, 2007). I follow this recent work in using an index of institutional coordination as a measurement of $\mathrm{VoC}$, rather than attribute a VoC category to each country.

Second, Amable and Azizi (2014) examine a long time period, from 1980-2009. However, the 2008-2010 period constitutes a rupture from the earlier years on two important counts. First, at no time during the period Amable and Azizi cover 
was there a protracted economic downturn of such magnitude across nearly all of the OECD. Second, governments turned toward discretionary fiscal stimulus during this period almost without exception. There is good reason, then, to consider the 2008-2010 time period as a discrete moment, in order to ask the question: how well can $\mathrm{VoC}$ explain the extent of discretionary fiscal stimulus in an unprecedented moment of crisis?

\section{Theories and data}

The implication of the Soskice model is that the more coordinated a market economy is, the more likely it will be to internalize demands for greater stimulus. I will test this hypothesis against three alternative theories.

First, while institutions are important, it is not the $\mathrm{VoC}$ institutions that matter so much as fiscal institutions. A series of studies have sought to show how and what kinds of rules can restrict the choices that politicians can make when it comes to public spending and taxation, including executive flexibility, amendment powers, access to information, and so forth (Hallerberg et al., 2001; von Hagen, 1992; 2003; von Hagen \& Harden, 1994; Wehner, 2006). Hence, more restrictive budgetary institutions could dampen stimulus measures.

Another possibility is that governments' concerns with debt credibility will limit the extent of discretionary fiscal stimulus. The logic here is that, for fiscal expansion to generate economic growth, bond markets need to be confident that governments will fulfill their financial obligations. Discretionary fiscal stimulus expands governments' commitments to domestic and international creditors through its increased stress on budgets and total government debt, while potentially signaling excessive liabilities to bond markets. This hypothesis follows from David Cameron's (2012) argument that budgetary constraint was the primary predictor of fiscal stimulus size during this time period.

Finally, there is the question of party politics. Following Hibbs (1977), an immense body of scholarship has examined the expectation that partisan politics matters for understanding a variety of policy outcomes, including budgetary expansion/contraction and welfare state retrenchment/maintenance (see, e.g., Breunig, 2011; Breunig \& Busemeyer, 2014; Jensen \& Mortensen, 2014; Cusack, 1997; Jensen, 2010). Recent studies have suggested that the impact of party politics in understanding fiscal policy in response to recession (Armingeon, 2012; Raess \& Pontusson, 2015) is limited. Left parties are assumed to push for 
lower unemployment, higher social spending, and greater income equality. The expectation here is that greater left party power will propel governments to enact greater stimulus measures.

For the dependent variable, I use OECD data on the magnitude of discretionary fiscal stimulus measures - total combination of tax cuts and spending increasesbetween 2008 and 2010, as a percentage of 2008 GDP (OECD, 2010). The values of this variable are positive for stimuli and negative for adjustment. This measurement excludes automatic stabilizers and avoids post hoc assessments of stimulus, like its effects on economic growth, government debt, inequality, and so forth.

For the $\mathrm{VoC}$ variable, the principal indicator is the degree of institutional coordination. Institutional coordination constitutes the degree to which firms in a production regime are empowered by the institutional complementarities in which they are embedded. Although different measurements of coordination exist in the literature, I use Knell and Srholec's (2007) coordination index (KS hereafter). Inspired by a working paper version of Hall and Gingerich's (2009) use of factor analysis to build a quantitative measurement of coordination, KS consists of an additive index, constructed from the results of factor analysis loadings for social cohesion, labor market regulation, and business regulation. ${ }^{1} \mathrm{KS}$ has several advantages over Hall and Gingerich's (2009) index. First, it uses more recent data. Second, while Hall and Gingerich use 20 OECD countries for their factor analysis, KS uses 51 countries, which make their factor loadings more plausible. Third, $\mathrm{KS}$ includes several East European and non-European countries for comparative purposes, some of which are used in the current analysis.

To test the fiscal institutions hypothesis, I use Wehner's (2006) index of legislative budget institutions. This index comprises six institutional prerequisites for legislative control: amendment powers, reversionary budgets, executive flexibility during budget execution, the timing of the budget, legislative committees, and budgetary information. All data is from a 2003 OECD-World Bank collaborative survey of specially identified budgetary officials in 36 countries, including all but 2 of the countries in the current study (see Wehner,

For each of these three composites, there are four variables, as follows: for social cohesion, inequality, marginal personal income tax rate, marginal corporate tax rate, and public spending; for labor market regulation, World Bank-administered surveys regarding the difficulty of hiring workers, firing workers, cost of firing workers, and rigidity of working hours; and for business regulation, from the same World Bank source, difficulty to register a business, time to resolve insolvency, difficulty to register property, and stock market-to-banking sector ratio in the financial system. For more information on the factor loadings, see Knell and Srholec, 2007, pp. 42-45. 
2006, pp. 774-776 for more details). Values range from 16.7 (Ireland) to 88.9 (United States). Previous statistical evidence suggests that legislative oversight generally increases fiscal discipline (Strauch \& von Hagen, 1999; von Hagen, 1992), so I expect a negative coefficient for this variable - the greater the legislative oversight, the smaller the discretionary stimulus.

For the debt credibility model, I use a simple measurement of government debt: total government liabilities as a per cent of GDP. I hypothesize a negative coefficient for the debt variable, the expectation being that the size of a government's liabilities will induce fiscal restraint.

For the partisan politics model, the key variable is the strength of left parties. The expectation is that left power ought to increase the size of fiscal stimulus. I measure left power as a percentage of seats held by left parties, as compiled from the Comparative Political Dataset III (CPDIII hereafter) (Armingeon et al., 2011). While the literature on policy change has achieved a modest consensus on the idea that constitutional structures have an impact on the capacity of political parties to effect policy change (Kuhner, 2010), CPDIII does not contain a measurement of constitutional structures for the East European cases, so I rely solely on left party strength.

Finally, I include four controls. First, since this paper supposes that governments enacted discretionary fiscal stimulus principally in response to the social consequences of the economic downturn, I include an unemployment rate variable. I expect greater unemployment to be associated with greater fiscal stimulus. Second, I control for the GDP growth/contraction, the intuition being that the greater the decline in GDP, the more fiscal resources governments will be willing to commit. Third, I include a rough measure of trade openness; total exports plus total imports. Given the sensitivity of fiscal stimulus and adjustments to import/export "leakage", the greater the value of trade openness, the smaller the stimulus is likely to be. Finally, I include a measure of governments' bank bailout costs, the intuition being that their size will have a negative impact on countries' willingness to commit additional fiscal resources to bolstering the economy. Data for this last control comes from Laeven and Valencia (2012), the rest is from the OECD. 


\section{Analysis}

The relationship between the two core variables - fiscal stimulus and variety of capitalism-is depicted in Figure 1 (a total of 23 observations). This scatterplot shows a decline in the level of fiscal stimulus as the degree of market coordination rises. The relationship is fairly steady, with no strong outliers. The use of the $\mathrm{KS}$ index to measure institutional coordination makes the positioning of certain cases surprising, given the standard understanding of these regimes. While most regimes usually considered LMEs do cluster at one end of the coordination axis, the ordering of the remaining regimes is unordinary. Greece shows up as the most coordinated regime, with France showing up as the second most coordinated (more coordinated than Italy, Germany and the Scandinavian countries). The other "mixed market economies" appear in the midst of the CMEs. Other unusual placings include Finland, which is scarcely less coordinated than Great Britain according to KS, and Canada showing up as the least coordinated market economy. Greece is also a somewhat special case in Figure 1 since, over the three years being analyzed, its discretionary fiscal stance was contractionary, not expansionary. But I include Greece since its austerity did not begin until later in 2010, after its sovereign debt crisis had begun. Until then, Greek governments had tried to address the recession with expansionary fiscal policy. ${ }^{2}$

I test the VoC hypothesis against its competitors using OLS regression. ${ }^{3}$ I regress the stimulus variable on the four independent variables representing each modelcoordination, fiscal institutions, debt, and left party strength - along with the four control variables - growth rate, unemployment, trade openness, and bailout costs. I include different model specifications for 2008 and 2009 versions of the debt, left party, growth, unemployment and trade openness variables, since either year's data could plausibly serve as the pertinent indicators. I also include specifications with and without control variables. Due to missing data on fiscal institutions for Poland and Switzerland, I exclude them from the analysis.

2 In the results that I follow, I ran regression models without Greece, and the results did not vary substantially. I can provide these results upon request.

3 Given the small number of cases, Bayesian econometrics would be an alternative to multivariate analysis. However, I used the latter tool in order to conform to other analyses of fiscal policy change in the literature, the majority of which do not use Bayesian modeling. 
Figure 1. Fiscal Stimulus and Institutional Coordination, 2008-2010.

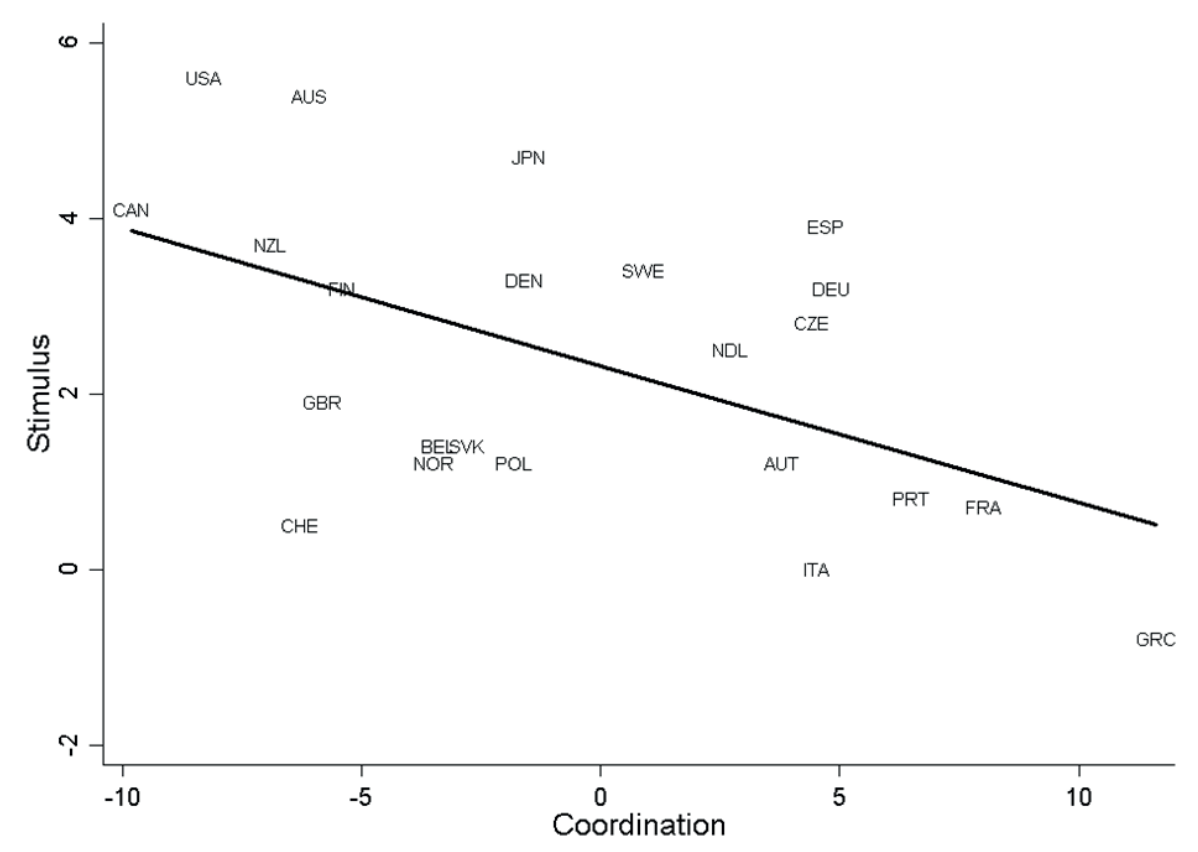

Table 1 displays all regression results. The evidence is encouraging. In each of the four model specifications, the estimated coefficient for the coordination variable is negative, and it is consistently the largest coefficient in the model. The negative relationship is precisely what is predicted by the model: the more coordinated the economy, the smaller the fiscal stimulus. As measured by the impact on fiscal balance, the fiscal stimulus will decrease by .147 per cent of GDP (or .131 per cent in the 2009 specification) for every unit increase in the degree of institutional coordination. In the two specifications that include the control variables, the coordination coefficients are statistically significant at either the 90 or 95 per cent level. The left party and debt variables, on the other hand, show exceptionally small coefficients and are never statistically significant. ${ }^{4}$ The fiscal institutions variable is statistically significant at the 90 per cent level when the control variables are included in the model, and the positive sign suggests that, contrary to the theory, higher levels of legislative constraint increase the degree of fiscal stimulus. However, the impact of this variable is quite small compared to the coordination variable. Meanwhile, among the control variables,

4 The weak showing of the partisanship variable supports Raess and Pontusson's (2015) study of the past three decades of discretionary fiscal policy responses to recession, as well as an earlier version of the current study (Toloudis, 2012). 
trade openness shows up as statistically significant in the 2008 specification, but not in 2009, while no other controls yield statistically significant results. The null hypothesis therefore can be rejected with reasonable confidence (especially given the small number of cases) for the core IV, coordination, but not for the debt and left party strength variables. The fiscal institutions variable performs better, but it shows up as statistically significant in fewer specifications and at lower signification levels. Given the small number of observations, these findings beg for further testing. On the basis of the current analysis, however, institutional coordination explains the extent of discretionary fiscal stimulus more powerfully than the competing variables.

Table 1. Regression results.

\begin{tabular}{|c|c|c|c|c|}
\hline & 2008 data & $\begin{array}{c}2008 \text { data, } \\
\text { including } \\
\text { controls }\end{array}$ & 2009 data & $\begin{array}{c}2009 \text { data, } \\
\text { including } \\
\text { controls }\end{array}$ \\
\hline Coordination & $-.168^{* * *}$ & $\begin{array}{c}-.147^{* *} \\
(.056)\end{array}$ & $\begin{array}{c}-.172^{* * *} \\
(.067)\end{array}$ & $\begin{array}{c}-.131^{*} \\
(.069)\end{array}$ \\
\hline Left party strength & .001 & -.005 & .000 & -.003 \\
& $(.016)$ & $(.010)$ & $(.010)$ & $(.011)$ \\
\hline Debt & -.002 & -.008 & .001 & -.005 \\
& $(.010)$ & $(.010)$ & $(.009)$ & $(.010)$ \\
\hline Fiscal institutions & .027 & $.035^{*}$ & .027 & $.039^{*}$ \\
& $(.019)$ & $(.019)$ & $(.018)$ & $(.020)$ \\
\hline CONTROLS & & & & \\
\hline Unemployment & & .007 & & .134 \\
& & $(.173)$ & & $(.120)$ \\
\hline Growth & & .376 & & .100 \\
& & $(.314)$ & & $(.180)$ \\
\hline Trade openness & & $-.025^{* *}$ & & -.015 \\
& & $(.011)$ & & $(.011)$ \\
\hline Bailout costs & & -.004 & & -.026 \\
& & $(.031)$ & & $(.031)$ \\
\hline R2 & .470 & .642 & .467 & .612 \\
\hline $\mathrm{N}$ & 21 & 21 & 21 & 21 \\
\hline
\end{tabular}

Notes: standard errors in parentheses;

* significant at $90 \%$,

** significant at $95 \%$,

*** significant at $99 \%$ 


\section{Conclusion}

The question that drives this paper is whether $\mathrm{VoC}$, a framework that assumes that regimes are concerned primarily with fiscal tightening, can predict the extent of budgetary loosening when most governments, in response to the commonly experienced crisis of 2008-2010, chose fiscal stimulus as a policy option. Multivariate analysis using recent data provides evidence that VoC logic explains fiscal expansion more powerfully than three plausible alternatives. During the 2008-2010 period, governments in more institutionally coordinated countries engaged in greater discretionary fiscal stimulus measures than governments in less institutionally coordinated countries. The article thereby contributes to the growing literature about policy responses to the Great Recession. In particular, it complements recent efforts to explain different quantities and qualities of fiscal stimulus in response to economic crisis (Armingeon, 2012; Cameron, 2012; Raess \& Pontusson, 2015). Raess and Pontusson (2015, p. 6) allude to, but sidestep the question of whether "different political-economy clusters" provide analytical leverage in explaining expansionary macroeconomic policy. The current paper is an effort to answer this question. Only fine-grained process tracing of key case studies can verify the causal logic with precision, but this analysis suggests that institutional complementarities help to explain the extent of the OECD's fiscal expansion that preceded the sovereign debt's crisis' inauguration of the austerity era.

\section{Acknowledgements}

An early version of this paper was prepared for presentation at the Annual Meeting of the American Political Science Association in 2012. My thanks to Timothy Hicks, who sent me comments on the paper in his role as APSA panel discussant, even though the conference was cancelled due to Hurricane Sandy. In addition, my thanks to Daniel Bowen, Brian Potter, and Jeffrey Selinger for their comments on later versions of this paper.

Nicholas Toloudis (PhD from Columbia University in 2006) is an Assistant Professor of Political Science at The College of New Jersey. He is the author of Teaching Marianne and Uncle Sam (Temple University Press, 2012). His current research is about changing patterns of contentious politics in response to the financial crisis in Europe. 


\section{References}

Amable, B. \& Azizi, K. (2014), 'Counter-cyclical budget policy across varieties of capitalism,' Structural Change and Economic Dynamics, vol. 30, pp. 1-9. http://dx.doi.org/10.1016/j.strueco.2014.01.001

Armingeon, K. (2012), 'The politics of fiscal responses to the crisis of 2008-2009,' Governance, vol. 25, no. 4, pp. 543-565. http://dx.doi.org/10.1111/j.14680491.2012.01594.x

Armingeon, K.; Knöpfel, L.; Weisstanner, D.; Engler, S.; Potolidis, P. \& Gerber, M. (2011), Comparative Political Data Set III, 1960-2009, Institute of Political Science, University of Berne. Retrieved from http://www.ipw.unibe.ch/ content/team/klaus_armingeon/comparative_political_data_sets/index_ger.html [accessed 7 Aug 2015]

Bermeo, N. \& Pontusson, J. (2012), 'Coping with Crisis: An Introduction,' in N. Bermeo \& J. Pontusson (eds.) Coping with Crisis: Government Reactions to the Great Recession, NY: Russell Sage Foundation, pp. 1-31.

Breunig, C. \& Busemeyer, M. R. (2012), 'Fiscal austerity and the trade-off between public investment and social spending,' Journal of European Public Policy, vol. 19, no. 6, pp. 921-938. http://dx.doi.org/10.1080/13501763.2011.614158

Cameron, D. R. (2012), 'European Fiscal Responses to the Great Recession,' in N. Bermeo \& J. Pontusson (eds.) Coping with Crisis: Government Reactions to the Great Recession, NY: Russell Sage Foundation, pp. 91-129.

Campbell, J. L. \& Pedersen, O. K. (2007), 'The Varieties of Capitalism and Hybrid Success: Denmark in the Global Economy,' Comparative Political Studies, vol. 40, no. 3, pp. 307-332. http://dx.doi.org/10.1177/0010414006286542

Carney, R. (2006), 'Varieties of Capitalism in France: Interests, Institutions, and France,' French Politics, vol. 4, no. 1, pp. 1-30.

Culpepper, P. D. (2007), 'Small States and Skill Specificity: Austria, Switzerland, and Interemployer Cleavages in Coordinated Capitalism,' Comparative Political Studies, vol. 40, no. 6, pp. 611-637. http://dx.doi.org/10.1177/0010414006295927

Cusack, T. (1997), 'Partisan Politics and Public Finance,' Public Choice, vol. 91, pp. 375-395. http://dx.doi.org/10.1023/A:1004995814758

Hall, P. \& Gingerich, D. (2009), 'Varieties of Capitalism and Institutional Complementarities in the Political Economy: An Empirical Analysis,'British Journal of Political Science, vol. 39, no. 4, pp. 449-482. http://dx.doi.org/10.1017/ S0007123409000672

Hall, P. \& Soskice, D., eds. (2001), Varieties of Capitalism: The Institutional Foundations of Comparative Advantage, New York: OUP. http://dx.doi. org/10.1093/0199247757.001.0001 
Hall, P. \& Thelen, K. (2009), 'Institutional Change in Varieties of Capitalism,' Socioeconomic Review, vol. 7, no. 1, pp. 7-34. http://dx.doi.org/10.1093/ser/mwn020

Hallerberg, M.; Strauch, R.; von Hagen, J. (2007), 'The design of fiscal rules and forms of governance in European Union,' European Journal of Political Economy, vol. 23, no. 2, pp. 338-359. http://dx.doi.org/10.1016/j.ejpoleco.2006.11.005

Hancké, B., ed. (2009), Debating Varieties of Capitalism: A Reader, New York: OUP.

Hibbs, D. (1977), 'Political Parties and Macroeconomic Policy,' American Political Science Review, vol. 71, no. 4, pp. 1467-1487. http://dx.doi.org/10.2307/1961490

Iversen, T. \& Soskice, D. (2006), 'New Macroeconomics and Political Science,' Annual Review of Political Science 9, pp. 425-453. http://dx.doi.org/10.1146/annurev. polisci.9.072004.085858

Jensen, C. (2010), 'Issue compensation and right-wing government social spending,' European Journal of Political Research, vol. 49, no. 2, pp. 282-299. http://dx.doi.org/10.1111/j.1475-6765.2009.01898.x

(2011), 'Capitalist Systems, Deindustrialization, and the Politics of Public Education,' Comparative Political Studies, vol. 44, no. 4, pp. 412-435. http://dx.doi.org/10.1177/0010414010393475

Jensen, C. \& Mortensen, P. (2014), 'Government Responses to Fiscal Austerity: The Effect of Institutional Fragmentation and Partisanship,' Comparative Political Studies, vol. 47, no. 2, pp. 143-170. http://dx.doi.org/10.1177/0010414013488536

Knell, M. \& Srholec, M. (2007), 'Diverging Pathways in Eastern and Central Europe,' in D. Lane \& M. Myant (eds.) Varieties of Capitalism in Post-Communist Countries, New York: Palgrave Macmillan, pp. 40-64.

Kuhner, S. (2010), 'Do Party Governments Matter After all? Executive Ideology, Constitutional Structures and their Combined Effect on Welfare State Change,' Journal of Comparative Policy Analysis, vol. 12, no. 4, pp. 395-415. http://dx.doi. org/10.1080/13876988.2010.495507

Laeven, L. \& Valencia, F. (2012), Systemic Banking Crises Database: An Update, IMF Working Paper No. 12/163.

OECD (2010), Factbook 2010: Economic, Environmental, and Social Statistics, Paris, France: OECD Publishing. Retrieved from http://www.oecd-ilibrary.org/ economics/oecd-factbook-2010_factbook-2010-en [accessed 7 Aug 2015]

Pontusson, J. \& Raess, D. (2012a), 'How (and Why) Is This Time Different? The Politics of Economic Crisis in Western Europe and the United States,' Annual Review of Political Science, vol. 15, pp. 13-33. http://dx.doi.org/10.1146/annurevpolisci-031710-100955

- (2012b), 'The Politics of Economic Crisis in Historical-Comparative Perspective,' Swiss Political Science Review, vol. 18, no. 4, pp. 502-507.

Raess, D. \& Pontusson, J. (2015), 'The politics of fiscal policy during economic downturns,' European Journal of Political Research, vol. 54, no. 1, pp. 1-22. http://dx.doi.org/10.1111/1475-6765.12074 
Schmidt, V. (2003), 'French capitalism transformed, yet still a third variety of capitalism,' Economy and Society, vol. 32, no. 4, pp. 526-554.

http://dx.doi.org/10.1080/0308514032000141693

Schneider, M. R. \& Paunescu, M. (2012), 'Changing Varieties of Capitalism and Revealed Comparative Advantages from 1990 to 2005: a Test of the Hall and Soskice Claims,' Socio-Economic Review, vol. 10, pp. 1-23.

http://dx.doi.org/10.1093/ser/mwr038

Soskice, D. (2007), 'Macroeconomics and Varieties of Capitalism,' in B. Hancké (ed.) Beyond Varieties of Capitalism, New York: OUP, pp. 89-121. http://dx.doi.org/10.1093/acprof:oso/9780199206483.003.0003

Thelen, K. (2009), 'Institutional Change in Advanced Political Economies,' British Journal of Industrial Relations, vol. 47, no. 3, pp. 471-498. http://dx.doi.org/10.1111/j.1467-8543.2009.00746.x (2004), How Institutions Evolve: The Political Economy of Skills in Germany, Britain, the United States, and Japan, New York: Cambridge University Press. http://dx.doi.org/10.1017/CBO9780511790997

Toloudis, N. (2012), 'Varieties of Capitalism and Fiscal Stimulus, 2008-2009.' Paper presented at the Annual Meeting of the American Political Science Association (cancelled due to Hurricane Sandy).

Tsebelis, G. \& Chang, E. (2004), 'Veto players and the structure of budgets in advanced industrialized countries,' European Journal of Political Research, vol. 43, no. 3, pp. 449-476. http://dx.doi.org/10.1111/j.1475-6765.2004.00161.x

von Hagen, J. (1991), 'A Note on the Empirical Effectiveness of Formal Fiscal Restraints,' Journal of Public Economics, vol. 44, pp. 199-210.

http://dx.doi.org/10.1016/0047-2727(91)90025-W

(1992), 'Budgeting Procedures and Fiscal Performance in the European Communities,' Economic Papers, vol. 96, pp. 1-79.

- (2002), 'Fiscal Rules, Fiscal Institutions, and Fiscal Performance,' The Economic and Social Review, vol. 33, no. 3, pp. 263-284.

von Hagen, J. \& Harden, I. (1994), 'Budget Processes and Commitment to Fiscal Discipline,' European Economic Review, vol. 39, pp. 771-779. http://dx.doi.org/10.1016/0014-2921(94)00084-D

Wehner, J. (2006), 'Assessing the Power of the Purse: An Index of Legislative Budget Institutions,' Political Studies, vol. 54, no. 4, pp. 767-785. http://dx.doi.org/10.1111/j.1467-9248.2006.00628.x 